\title{
Carolyn Chen, Getting Saved in America: Taiwanese Immigration and Religious Experience
}

Princeton - Oxford, Princeton University Press, 2008, 230 pp.

\section{Hayet Sellami}

\section{OpenEdition}

\section{Journals}

Electronic version

URL: http://journals.openedition.org/chinaperspectives/4826

DOI: $10.4000 /$ chinaperspectives. 4826

ISSN: 1996-4617

\section{Publisher}

Centre d'étude français sur la Chine contemporaine

Printed version

Date of publication: 1 June 2009

Number of pages: 128-129

ISSN: 2070-3449

\section{Electronic reference}

Hayet Sellami, « Carolyn Chen, Getting Saved in America: Taiwanese Immigration and Religious

Experience », China Perspectives [Online], 2009/2 | 2009, Online since 01 June 2009, connection on 22

September 2020. URL : http://journals.openedition.org/chinaperspectives/4826 ; DOI : https://doi.org/ 10.4000/chinaperspectives.4826

This text was automatically generated on 22 September 2020.

(C) All rights reserved 


\section{Carolyn Chen, Getting Saved in America: Taiwanese Immigration and Religious Experience}

Princeton - Oxford, Princeton University Press, 2008, 230 pp.

Hayet Sellami

Derived from a doctoral thesis, this book tells us about Taiwanese emigrants to the United States of America and the way that they become American, primarily through religion and more specifically through their conversion to Buddhism or evangelical Christianity. This phenomenon predominantly involves middle class Taiwanese who have settled in California's San Gabriel Valley. Confronting the American reality, its social structures and its traditions, these emigrants lose their bearings and then search for a new identity that will lead to the discovery of a "true self" in order to survive in their host country. Religion - and religious conversion in particular - the author tells us, transforms them into Americans.

2 The book is organised into five chapters in which themes, concepts, and testimonies intertwine. After an introduction summarising the religious themes of the "sacred" and "salvation" (1) in the context of migration, the author in Chapter One describes the social, political, and economic contexts of the immigration of this middle class to California and its subsequent religious experience. The transformation of local American churches into Buddhist temples or Taiwanese Christian churches illustrates the need of this middle class to nurture its traditions and its beliefs. The Christian church (Grace Evangelical Church) and Buddhist temple (Dharma Light Temple) in this study exemplify this establishment of Taiwanese religious institutions in the United States, the majority of which are financed by religious leaders in Taiwan and Taiwanese businessmen in the United States.

3 The following two chapters then focus on the conversion of these Taiwanese to (evangelical) Christianity and (Mahayana) Buddhism by giving a detailed account of their "religious transformation." The thesis argued by Chen is based on the central idea that these conversions support a new form of pluralist religion at the heart of the 
community of Taiwanese emigrants and provide the foundation necessary for these communities to emerge in the United States. The simple fact of converting to Christianity or Buddhism transforms their identity. Associated with moral discipline and religious traditions inherited from Taiwan, these conversions allow them to "become new-selves" (pp. 37-145).

Different scenarios come into play depending on the religion adopted. While a strategy of evangeli sation, fulfilling the need of this middle class to live in a community, allows the Christian church to create a place where people can meet and "get to know" each other, the Buddhist temple does no marketing work to attract members. Tension and fierce competition between the two religions divide the Taiwanese community on existential questions of God and the "meaning" of religion. The predominance of evangelical Christians in the Taiwanese community, their interpretation and practice of Christianity - the important work of evangelisation by the churches, prayer meetings held by the members, social and educational activities, daily church visits obliges the Buddhists to "rethink" their religion. Wishing to differentiate themselves from evangelical Christians, these previously involuntary and "unthinking" heirs of Buddhism "rediscover" their beliefs through the study of sutras and a more assiduous practice of the religion. Buddhism thus makes a radical move from a religion inscribed in Taiwanese culture to an "explicit" religion, providing its adherents with a social dimension and a dimension involving identity.

If conversion is liberating, it is likewise painful, for it involves the possible rejection of family and all the obligations and traditions attached to it (the worship of ancestors, for example). It remains, however, a personal and free choice. This abandonment of ancient traditions and the adoption of new ones is, according to the author, "transformational" in the process of reconstructing oneself and the family in the United States.

6 Chapter Four illustrates this "reconstruction of self" and of an identity through the use of religious models. By questioning the ancient traditions that defined them in days of old, the evangelical Christian and the Buddhist renounce what they once were while establishing "their true identity": the former is "reborn" while the latter will "awaken his/her true Buddha nature" (pp. 141 - 145). (2) The Christians define their new and true identity by responding to the "call of Christianity" and to the goal that is set for them. At church, they find a secure space where they can develop their true talents and take up positions of responsibility (through the church's volunteer work, activities, and management). The Buddhists concentrate on a transformation of the self through "the renunciation of oneself and worldly desires" (pp. 141-142) in the form of status and material success. Then follows a description of this transformation of identity, which, according to the author, manifests itself differently in men and women. Conversion through religious practices is an act of rebellion that liberates the women (Buddhist and Christian) from Confucian traditions and the hold exerted by the family, and that restores to the men a confidence lost during the experience of immigration, allowing them to face adversity (racism and competition), disappointment (the devaluation of skills), and insecurity (lack of promotion) in the professional world. Buddhism and evangelical Christianity allow their converts to manage and control their "interior beings" by believing in an "ethic" that keeps the actions, desires, and thoughts of the individual under control. In the context of the pluralist American society, religion is an identity resource. Taiwanese emigrants resort to it in order to resolve their problems of 
identity, to find their "true nature," and to create a community and a morality. Their religious experiences reflect a long American tradition in which religion plays a central role in the formation of communities and in the management of morality. By reformulating Confucian traditions in the teaching of religion, they transpose traditional values into American life. By becoming religious, the author concludes, they become American.

7 The work bears witness, in a condensed style, to the role of religious conversion in the integration of Taiwanese immigrants to the United States. In this sense, Carolyn Chen moves away from the core of studies mapped out since the 1980s by researchers working on immigration to the United States in terms of social structures such as the economy, education, and the political system. (3) In the author's opinion, it is necessary to take into consideration other criteria that are neither "quantifiable" nor easily observable from the outside: the profound changes working at the level of the individual's unconscious and reflected in his or her daily habits.

8 This book thus offers interesting points of view on the construction of identity and constitutes a good reference for understanding the family and religious traditions of the Taiwanese people: meaningful anecdotes, examples, and quotations, and a psychological approach. One notes, however, repetitions of themes already addressed in each chapter, and a certain redundancy also in sociological definitions - which crop up too frequently as footnotes - to throw light on the ideas put forward. In the end, the work seems to favour the theme of conversion and its role in the integration of Taiwanese into American society to the detriment of the context in which it emerges: immigration.

9 Translated by Nick Oates

\section{AUTHOR}

HAYET SELLAMI

Ph.D. Candidate in Sociology at EHESS, Paris and Research Fellow at the CEFC. 